Supporting Information

\title{
Engineering Nitrogen Vacancy in Polymeric Carbon Nitride for Nitrate Electroreduction to Ammonia
}

Yanmei Huang, ${ }^{1, \dagger}$ Jun Long, ${ }^{2,3, \dagger}$ Yuting Wang, ${ }^{1}$ Nannan Meng, ${ }^{1}$ Yifu Yu, ${ }^{1,}{ }^{*}$ Siyu Lu, ${ }^{4}$ Jianping Xiao, ${ }^{2,5, *}$ and Bin Zhang $^{1}$

${ }^{1}$ Institute of Molecular Plus, School of Science, Tianjin University, Tianjin 300072, China

${ }^{2}$ State Key Laboratory of Catalysis, Dalian Institute of Chemical Physics, Dalian 116023, China

${ }^{3}$ School of Science, Westlake University, Hangzhou 310024, China

${ }^{4}$ Green Catalysis Center, College of Chemistry, Zhengzhou University, Zhengzhou 450000, China

${ }^{5}$ Dalian National Laboratory for Clean Energy, Dalian 116023, China

${ }^{\dagger}$ These authors contributed equally to this work.

AUTHOR INFORMATION

\section{Corresponding Author}

*E-mail: yyu@tju.edu.cn; xiao@dicp.ac.cn 


\section{Experimental Section}

\subsection{Electrochemical performance tests}

The electrochemical performance tests were conducted on a CHI 650D workstation using a threeelectrode configuration within an H-cell (PCNV-x sample as the working electrode, saturated calomel electrode (SCE) as the reference electrode, and platinum foil as the counter electrode). $40 \mathrm{~mL}$ of 0.5 $\mathrm{M} \mathrm{Na}_{2} \mathrm{SO}_{4}$ (containing $100 \mathrm{ppm} \mathrm{NO}-\mathrm{N}$ ) solution was added into the cathode compartment and another $40 \mathrm{~mL}$ of $0.5 \mathrm{M} \mathrm{Na}_{2} \mathrm{SO}_{4}$ solution was added into the anode compartment. The pretreated Nafion 117 proton exchange membrane (Dupont) served as the separator. Before being applied in the electrochemical tests, the Nafion 117 membrane was treated by boiling in ultrapure water for $1 \mathrm{~h}$ and heating in $\mathrm{H}_{2} \mathrm{O}_{2}(5 \%)$ aqueous solution at $80{ }^{\circ} \mathrm{C}$ for another $1 \mathrm{~h}$. Before the test, linear sweep voltammetry (LSV) measurements were performed at a scan rate of $10 \mathrm{mV} \mathrm{s}^{-1}$ until the polarization curves were steady. Then, potentiostatic tests were conducted at different potentials for $2 \mathrm{~h}$. The same piece of working electrode was tested at the optimized potential for 5 cycles for the stability test. The electrolyte was changed to a fresh one for each cycle, and the other parameters were maintained the same.

\subsection{Determination of ion concentration.}

The ultraviolet-visible (UV-Vis) spectrophotometer was used to detect the ion concentration of preand post-test electrolytes after diluting to appropriate concentration to match the range of calibration curves. The concentration of ions was calculated by the corresponding standard calibration curve. The specific detection methods are as follow:

\section{Determination of nitrate-N:}

Firstly, a certain amount of electrolyte was taken out from the cathode compartment and diluted to 5 $\mathrm{mL}$. Then, $0.1 \mathrm{~mL} 1 \mathrm{M} \mathrm{HCl}$ and $0.01 \mathrm{~mL} 0.8 \mathrm{wt} . \%$ sulfamic acid solution were added into the above 
solution. The absorption intensities at the wavelength of $220 \mathrm{~nm}$ and $275 \mathrm{~nm}$ were recorded using an ultraviolet-visible spectrophotometer. The final absorbance value was calculated by the equation: $A=A_{220 \mathrm{~nm}}-2 A_{275 \mathrm{~nm}}$. The concentration-absorbance curve was calibrated using a series of standard potassium nitrate solutions and the potassium nitrate crystal was dried at $105{ }^{\circ} \mathrm{C}$ for $2 \mathrm{~h}$ in advance.

\section{Determination of nitrite- $N$ :}

A mixture of $p$-aminobenzenesulfonamide $(4 \mathrm{~g}), \mathrm{N}$-(1-Naphthyl) ethylenediamine dihydrochloride $(0.2 \mathrm{~g})$, ultrapure water $(50 \mathrm{~mL})$, and phosphoric acid $(10 \mathrm{~mL}, \rho=1.70 \mathrm{~g} / \mathrm{mL})$ was used as color reagent. A certain amount of electrolyte was taken out from the electrolytic cell and diluted to $5 \mathrm{~mL}$ to the detection range. Next, $0.1 \mathrm{~mL}$ color reagent was added into the $5 \mathrm{~mL}$ above solution and mixed evenly, and the absorption intensity at a wavelength of $540 \mathrm{~nm}$ was recorded after sitting for $20 \mathrm{~min}$. The concentration-absorbance curve was calibrated using a series of standard sodium nitrite solutions.

\section{Determination of ammonia-N:}

Ammonia-N was determined using the indophenol blue method. First, a certain amount of electrolyte was taken out from the reaction vessel and diluted to $2 \mathrm{~mL}$. Next, $1.0 \mathrm{~mL} \mathrm{NaOH}$ solution containing 5 $\mathrm{wt} \%$ salicylic acid and $5 \mathrm{wt} \%$ sodium citrates was added into the above solution, followed by adding $0.5 \mathrm{~mL}$ of $0.05 \mathrm{M} \mathrm{NaClO}$ and $0.05 \mathrm{~mL}$ of $1 \mathrm{wt} \% \mathrm{C}_{5} \mathrm{FeN}_{6} \mathrm{Na}_{2} \mathrm{O}$ (sodium nitroferricyanide) solution. The absorption intensity at a wavelength of $690 \mathrm{~nm}$ was recorded after sitting for $1 \mathrm{~h}$. The concentration-absorbance curve was calibrated using a series of standard ammonium chloride solutions.

\subsection{Calculation of conversion rate, yield rate, selectivity, and Faradaic efficiency.}

The conversion rate of nitrate:

Conversion $=\Delta c$ nitrate $/ c_{0} \times 100 \%$

The yield rate of ammonia: 
Yieldammonia $=c_{\text {ammonia }} \times V /\left(M_{\text {ammonia }} \times t \times m\right)$

The selectivity of ammonia:

Selectivityammonia $=c_{\text {ammonia }} / \Delta c$ nitrate $\times 100 \%$

The selectivity of nitrite:

Selectivitynitrite $=c$ nitrite $/ \Delta c$ nitrite $\times 100 \%$

The Faradaic efficiency (FE) of ammonia:

$\mathrm{FE}_{\text {ammonia }}=\left(8 \times F \times c_{\text {ammonia }} \times V\right) /\left(M_{\text {ammonia }} \times Q\right)$

Where $c$ is the concentration of ions, $\Delta c$ nitrate is the concentration difference of nitrate before and after electrolysis, $c_{0}$ is the initial nitrate concentration, $V$ is the volume of electrolyte in the cathode compartment (40 mL), Mammonia is the molar mass of ammonia, $t$ is the electrolysis duration, $m$ is the mass of catalyst, $F$ is the Faraday constant $\left(96485 \mathrm{C} \mathrm{mol}^{-1}\right), Q$ is the total charge passing the electrode.

\subsection{Isotope labelling experiments.}

Before the isotope labeling experiment, the calibration curve was established. First, a series of ${ }^{15} \mathrm{NH}_{4}-$ ${ }^{15} \mathrm{~N}$ solutions with known concentrations were prepared in $0.5 \mathrm{M} \mathrm{Na}_{2} \mathrm{SO}_{4}$ containing 50 ppm maleic acid $\left(\mathrm{C}_{4} \mathrm{H}_{4} \mathrm{O}_{4}\right.$, external standard). Second, the $\mathrm{pH}$ of the standard solution was also adjusted to 4 by adding 4.0 $\mathrm{M} \mathrm{H}_{2} \mathrm{SO}_{4}$. Third, $100 \mu \mathrm{L}$ deuterium oxide $\left(\mathrm{D}_{2} \mathrm{O}\right)$ was added in $0.5 \mathrm{~mL}$ above standard solution for the ${ }^{1} \mathrm{H}$ NMR detection; Fourth, the ${ }^{1} \mathrm{H}$ NMR spectrum was collected on an Ascend 600 NMR spectrometer equipped with an ultralow temperature probe. Water suppression mode was applied. Fifth, the calibration curve was achieved using the peak area ratio between ${ }^{15} \mathrm{NH}_{4}{ }^{+}$and maleic acid. Similarly, the amount of ${ }^{14} \mathrm{NH}_{4}{ }^{+}$was quantified by this method when $\mathrm{Na}^{14} \mathrm{NO}_{3}$ was used as the feeding $\mathrm{N}$ source. The ${ }^{15} \mathrm{~N}$ isotope labeling experiments were conducted under the same electrochemical 
performance test procedure, except the nitrate source was replaced by $\mathrm{Na}^{15} \mathrm{NO}_{3}(99.21 \%)$. After electrolysis, $0.5 \mathrm{~mL}$ electrolyte was extracted for the ${ }^{1} \mathrm{H}$ NMR test.

\subsection{In situ attenuated total reflection Fourier transform infrared (ATR-FTIR) spectroscopy.}

In situ ATR-FTIR spectra were collected on a Nicolet 6700 FTIR spectrometer with gold thin layer film enclothe silicon prismatic window. $2.5 \mathrm{mg}$ of catalyst and $20 \mu \mathrm{L} 50 \mathrm{wt} . \%$ Nafion solution were added into $1 \mathrm{~mL}$ absolute ethanol and ultrasonicated for $1 \mathrm{~h}$ to get homogenous ink. $60 \mu \mathrm{L}$ of ink was carefully dropped on the surface of gold film and used as the working electrode. Platinum foil and saturated calomel electrode (SCE) served as the counter electrode and reference electrode, respectively. 0.5 $\mathrm{M} \mathrm{Na}_{2} \mathrm{SO}_{4}$ solution (containing $100 \mathrm{ppm} \mathrm{NO}_{3}^{-}-\mathrm{N}$ ) was employed as the electrolyte. The background spectra of the working electrode were recorded at an open-circuit voltage before each measurement. The applied potential ranged from $-1 \mathrm{~V}$ to $-1.8 \mathrm{~V}$ with an interval of $0.1 \mathrm{~V}$.

\subsection{Online differential electrochemical mass spectrometry (DEMS) measurements.}

For the online DEMS test, carbon paper coated with a catalyst, platinum wire, and SCE electrode were employed as the working electrode, counter electrode, and reference electrode, respectively. 0.5 $\mathrm{M} \mathrm{Na}_{2} \mathrm{SO}_{4}$ electrolyte with 2000 ppm $\mathrm{NO}_{3}{ }^{-}-\mathrm{N}$ kept flowing through the homemade electrochemical cell through a peristaltic pump. The potentiostatic model was adopted. The potential was switched on and off periodically and the mass signal was collected 4 times.

\subsection{DFT calculations.}

All the density functional theory (DFT) calculations were performed on the Vienna Ab-initio Simulation Package ${ }^{1,2}$, with revised Perdew-Burke-Ernzerhof (rPBE) as the exchange-correlation functional $^{3}$. A cutoff energy of $400 \mathrm{eV}$ was applied, with a Gaussian smearing width of $0.2 \mathrm{eV}$. The DFT-D3 method of Grimme was used to describe the Van der Waals interactions. ${ }^{4}$ A Monkhorst-Pack 
$k$-point mesh grid of $(3 \times 3 \times 1)$ was used for Brillouin zone sampling. The convergence criteria were set to $0.05 \mathrm{eV} / \AA$ for all calculations.

The reaction free energies $(\Delta G)$ of electrochemical steps were calculated via the computational hydrogen electrode (CHE) model as following ${ }^{5}$.

$\Delta G=\Delta E_{\mathrm{DFT}}+\Delta E_{\mathrm{ZPE}}-T \Delta S-n e U$

Where the $\Delta E_{\mathrm{DFT}}$ is the electronic energy difference between reactants and products obtained via DFT calculations directly. $\triangle E_{Z P E}$ and $\Delta S$ are the difference in zero-point energy and entropy, respectively. $-n e U$ represents the effect of applied bias for proton-electron transfer reactions.

The adsorption free energy of $\mathrm{NO}_{3}^{-}\left[G_{\text {ad }}\left(\mathrm{NO}_{3}{ }^{-}\right)\right]$was calculated via Scheme $\mathrm{S} 1 . \Delta \mathrm{G}_{1}$ is the reaction free energy from gas $\mathrm{HNO}_{3}(\mathrm{~g})$ to adsorbed $\mathrm{NO}_{3} *$ and $\left(\mathrm{H}^{+}+\mathrm{e}^{-}\right)$and can be calculated using the $\mathrm{CHE}$ model. The free energy change from liquid $\mathrm{HNO}_{3}(\mathrm{l})$ to gas $\mathrm{HNO}_{3}(\mathrm{~g})$ was calculated from the difference in standard Gibbs free energy of formation between $\mathrm{HNO}_{3}$ in liquid and gas, which equals $0.075 \mathrm{eV}$. The free energy for $\mathrm{HNO}_{3}(\mathrm{l})$ formation from $\mathrm{NO}_{3}{ }^{-}$in an aqueous solution is $0.317 \mathrm{eV}$. These Gibbs free energies were all obtained from the $\mathrm{CRC}$ handbook of chemistry and physics. Finally, $\mathrm{G}_{\mathrm{ad}}\left(\mathrm{NO}_{3}{ }^{-}\right)$ $=\Delta G_{1}+0.075+0.317$ 


\section{Results and Discussions}
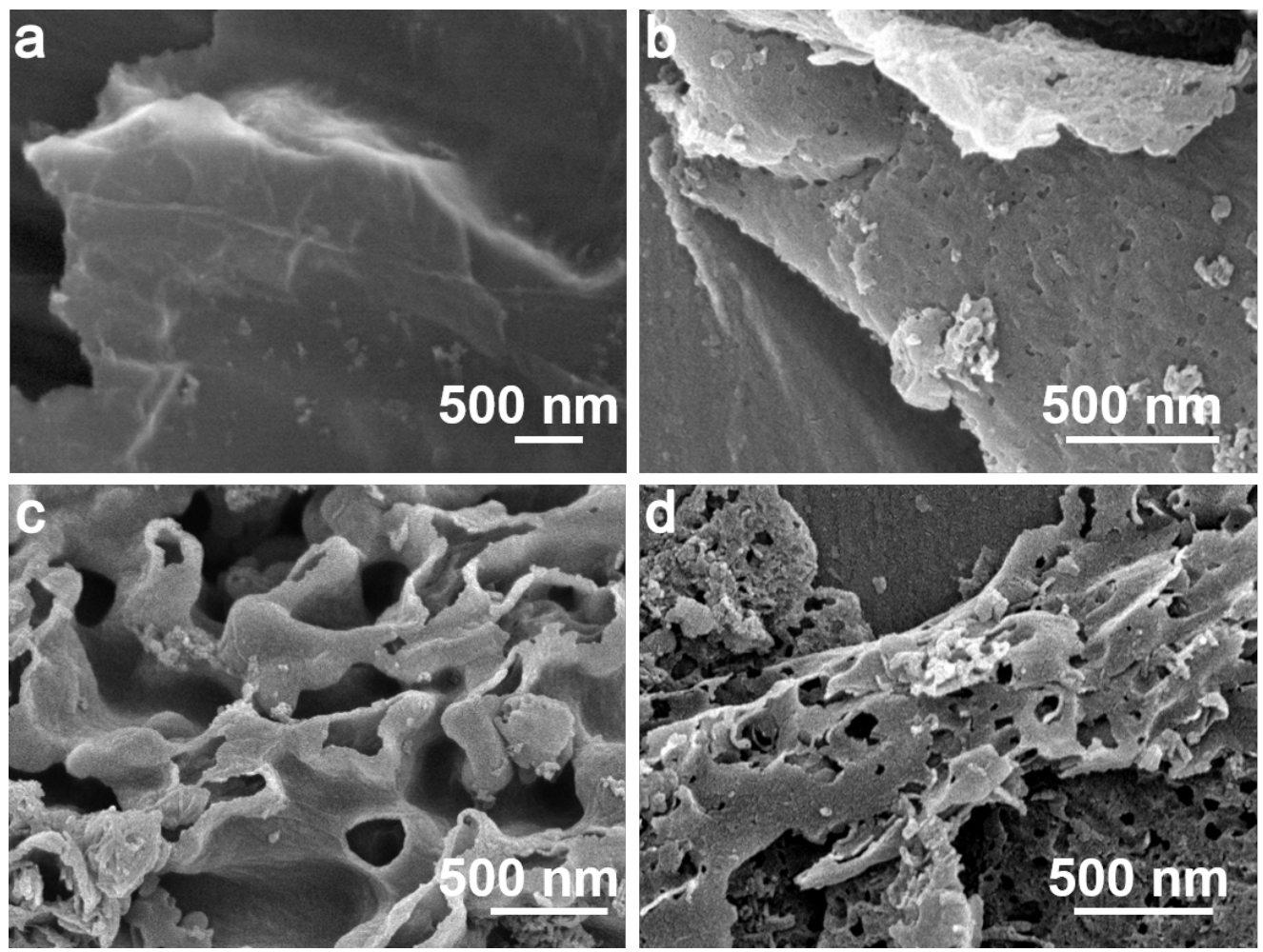

Figure S1. SEM images of a) BCN, b) PCNV-550, c) PCNV-600, and d) PCNV-650.

After calcination treatment, thick BCN aggregates are exfoliated into porous nanosheets. 

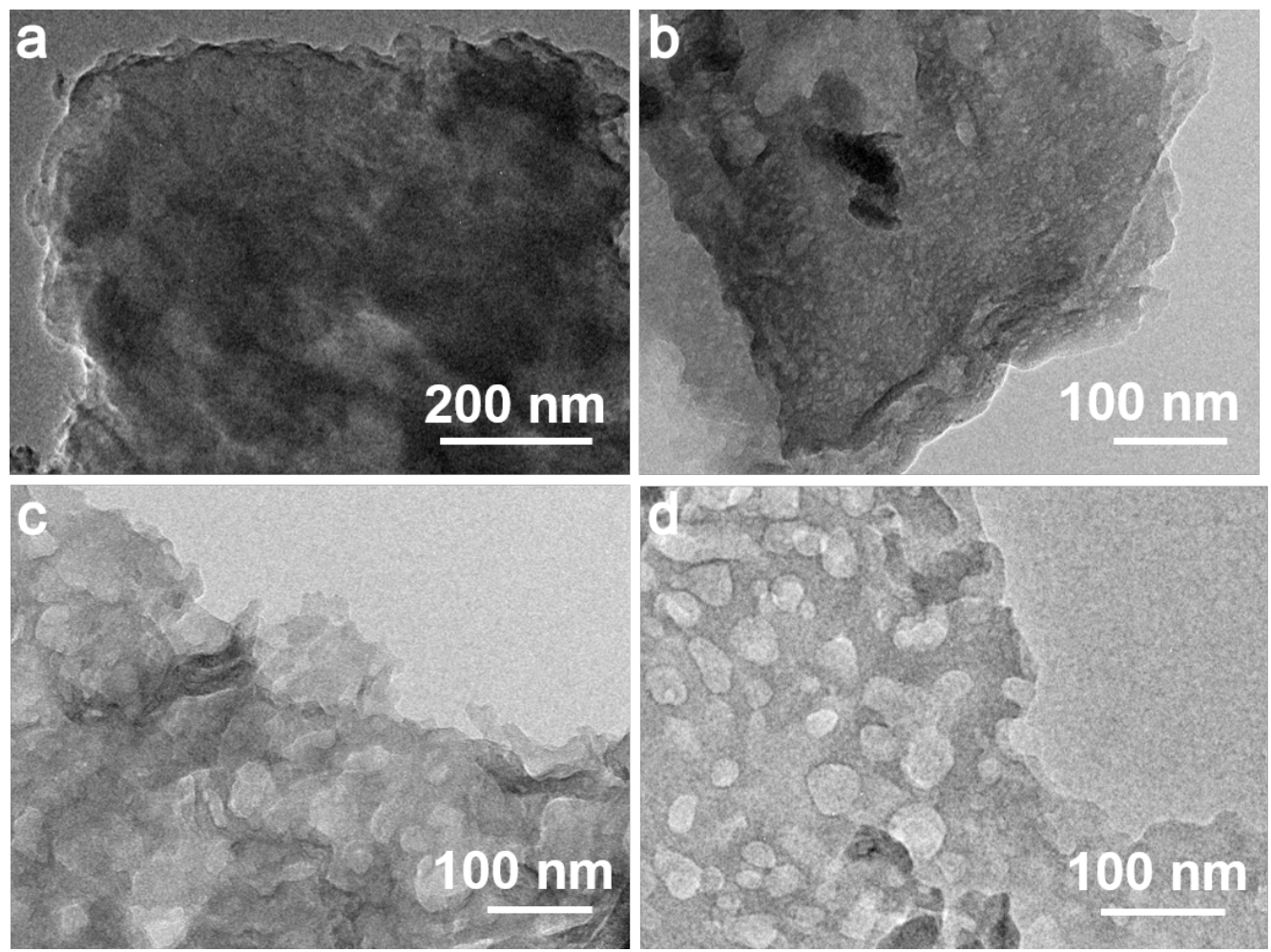

Figure S2. TEM images of a) BCN, b) PCNV-550, c) PCNV-600, and d) PCNV-650.

With the increase of calcination temperature, more pores appear and nanosheets become more transparent. 


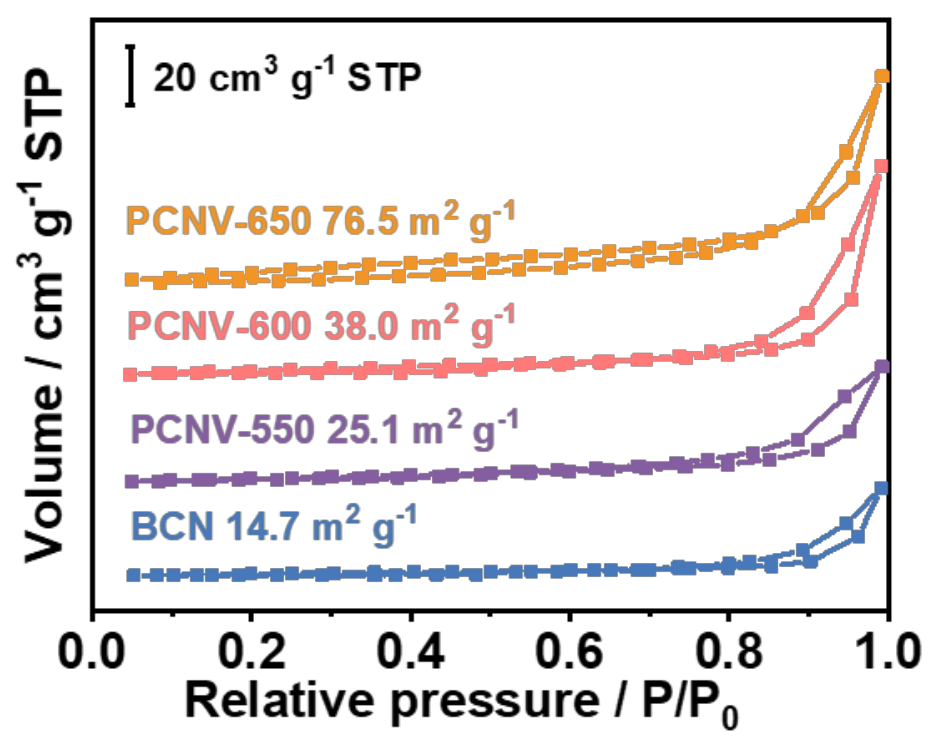

Figure S3. Nitrogen adsorption-desorption isotherms of all the samples.

The Brunauer-Emmett-Teller (BET) surface area is measured to be $14.7 \mathrm{~m}^{2} \mathrm{~g}^{-1}$ for BCN, $25.1 \mathrm{~m}^{2} \mathrm{~g}^{-1}$ for PCNV-550, $38.0 \mathrm{~m}^{2} \mathrm{~g}^{-1}$ for PCNV-600, and $76.5 \mathrm{~m}^{2} \mathrm{~g}^{-1}$ for PCNV-650, respectively. 


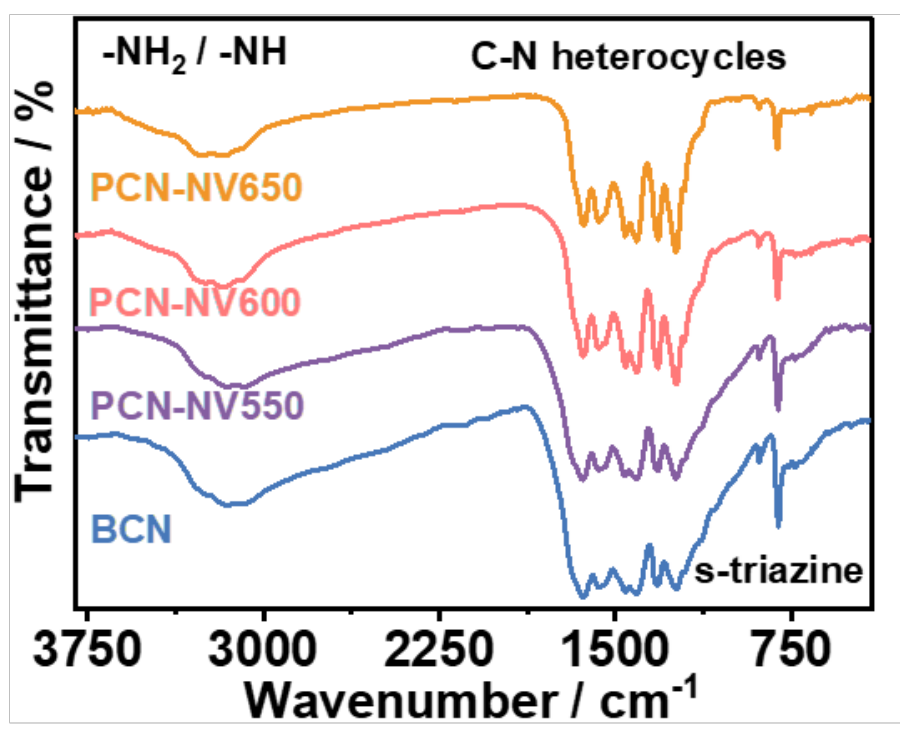

Figure S4. FTIR spectra of all the samples.

The peak at $810 \mathrm{~cm}^{-1}$ is ascribed to the out-of-plane bending mode of tri-s-triazine rings ${ }^{6}$. The peaks ranging from 1100 to $1600 \mathrm{~cm}^{-1}$ originate from the stretching modes of aromatic $\mathrm{C}-\mathrm{N}$ heterocycles ${ }^{7}$. The multiple broad peaks in the $3000-3500 \mathrm{~cm}^{-1}$ region correspond to the $\mathrm{N}-\mathrm{H}$ stretching vibrations ${ }^{6}$. All the PCNV-x samples show similar characteristic vibration peaks to $\mathrm{BCN}$, demonstrating the retaining of $\mathrm{C}_{3} \mathrm{~N}_{4}$ framework after calcination treatment. 


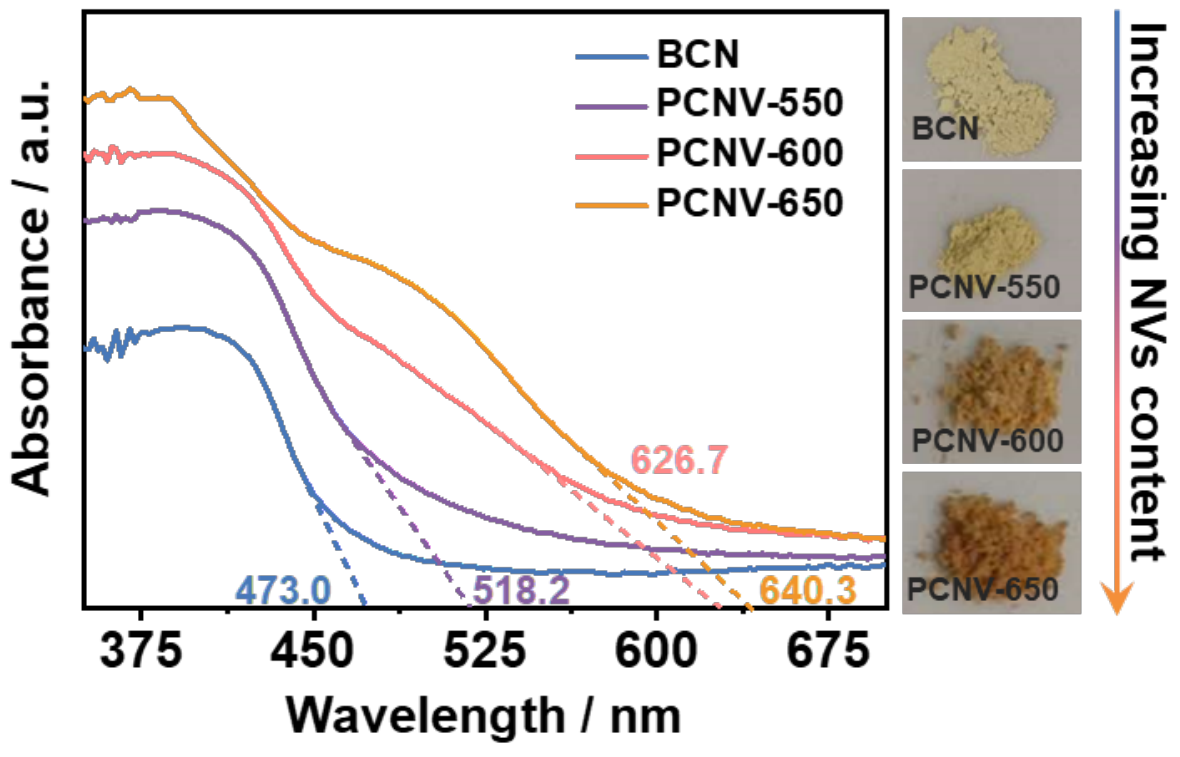

Figure S5. UV-vis spectra of all the samples.

With the increase of calcination temperature, the optical edge is extended to the visible region, verified by the color change from light yellow to brown. The improved absorption ability in the visible region can be ascribed to nitrogen vacancies. ${ }^{8}$ The more nitrogen vacancies, the stronger optical absorption ability. 

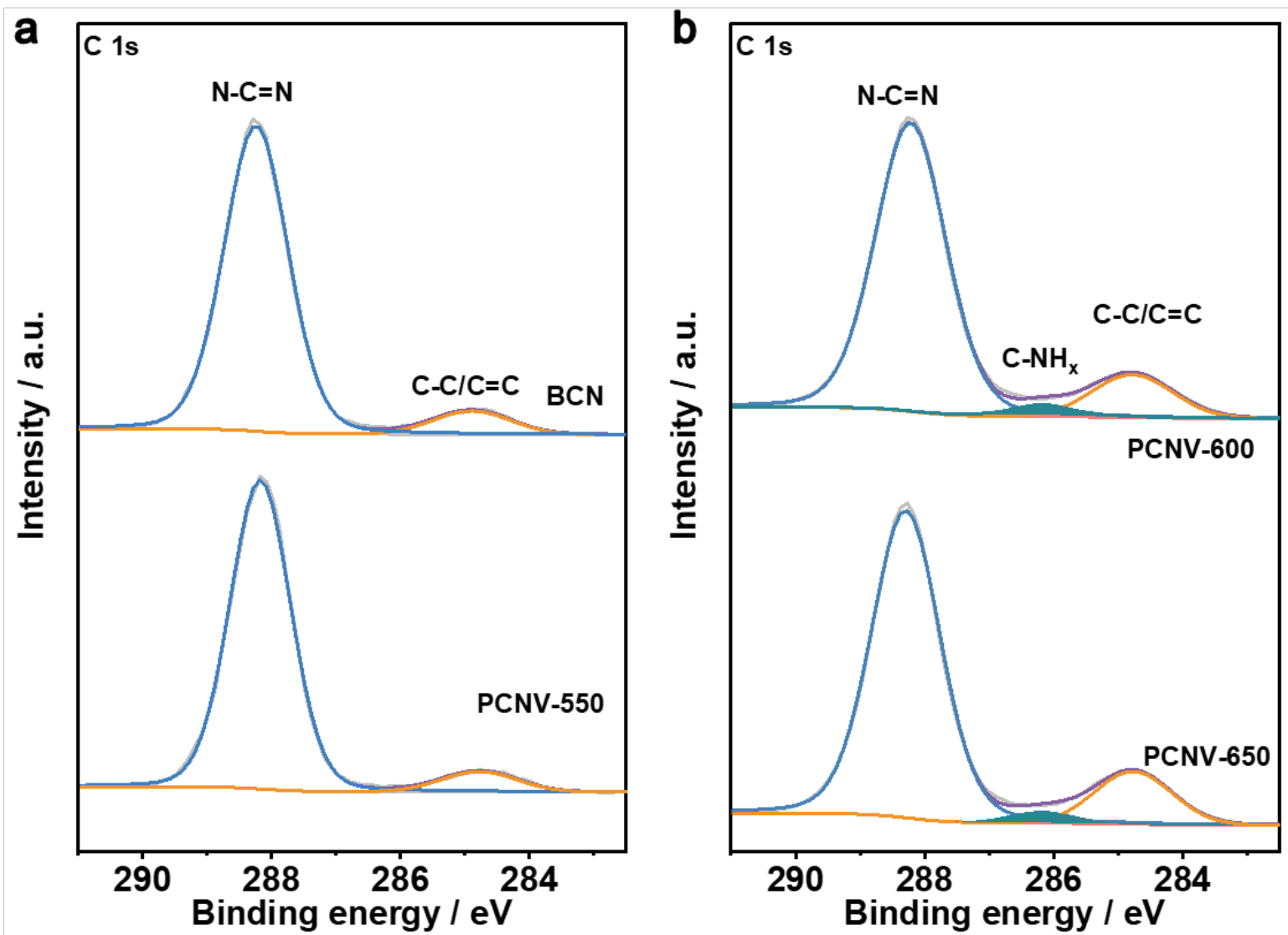

Figure S6. C1s XPS spectra of a) BCN and PCNV-550, and b) PCNV-600 and PCNV-650.

The C1s XPS peaks at $284.8 \mathrm{eV}$ and $288.2 \mathrm{eV}$ can be assigned to the adventitious carbon and typical $\mathrm{N}-\mathrm{C}=\mathrm{N}$ in aromatic $\mathrm{C}_{3} \mathrm{~N}_{4}$ heterocycles ${ }^{6}$, respectively (Figure S6). With the loss of $\mathrm{N}_{2} \mathrm{C}$ atoms, an additional binding energy peak at $286.2 \mathrm{eV}$ associated with $\mathrm{C}-\mathrm{NH}_{\mathrm{x}}(\mathrm{x}=1,2)$ is observed from PCNV600 and PCNV-650 (Figure S6b). ${ }^{9}$ 

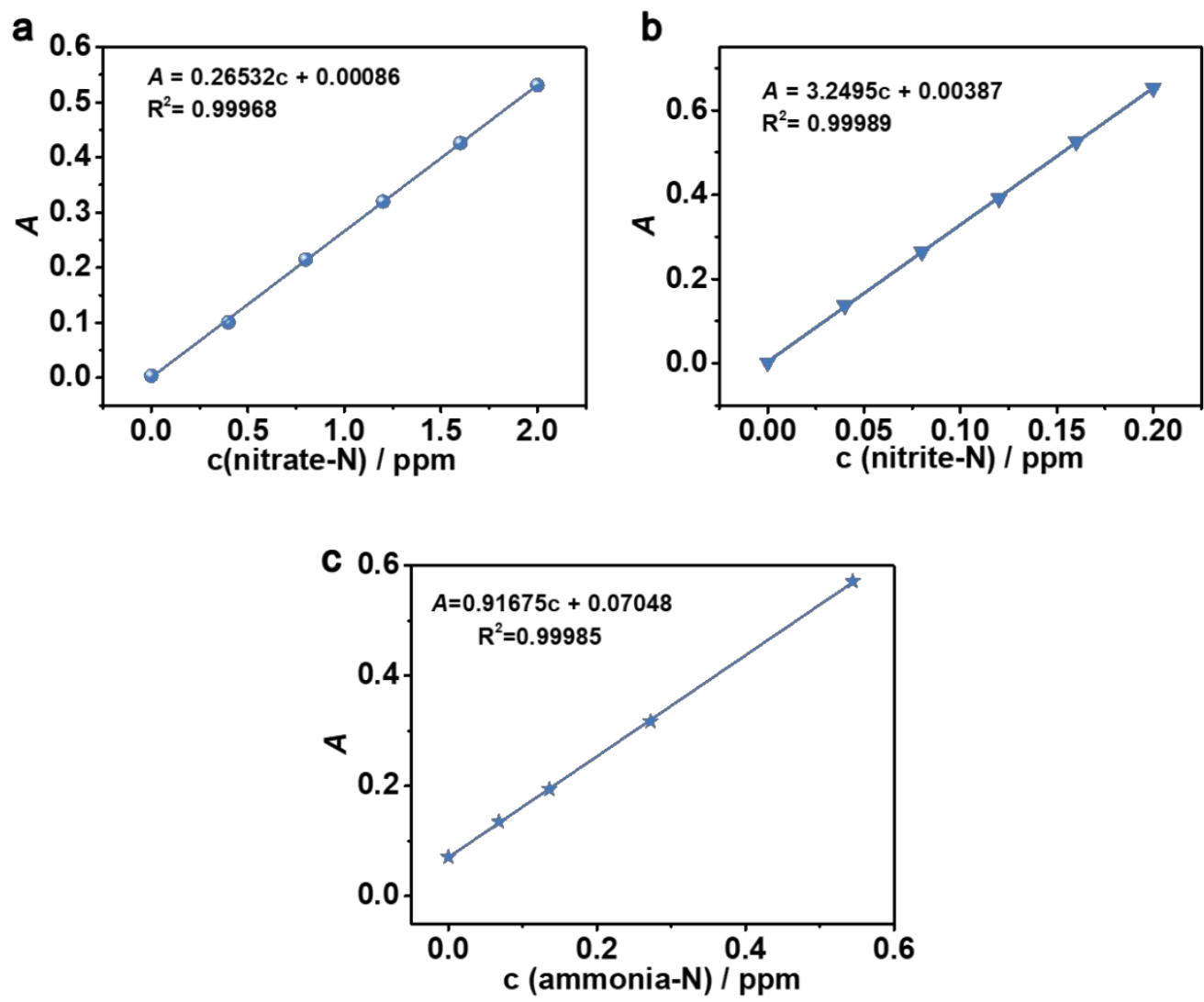

Figure S7. The concentration-absorbance calibration curves of a) nitrate-N, b) nitrite-N and c) ammonia-N.

The nitrate, nitrite, and ammonia concentrations are all referred to as nitrogen (nitrate-N, nitrite-N, ammonia-N), and $0.5 \mathrm{M} \mathrm{Na} 2 \mathrm{SO}_{4}$ is used as the background solution. The calibration curves all show good linearity. 

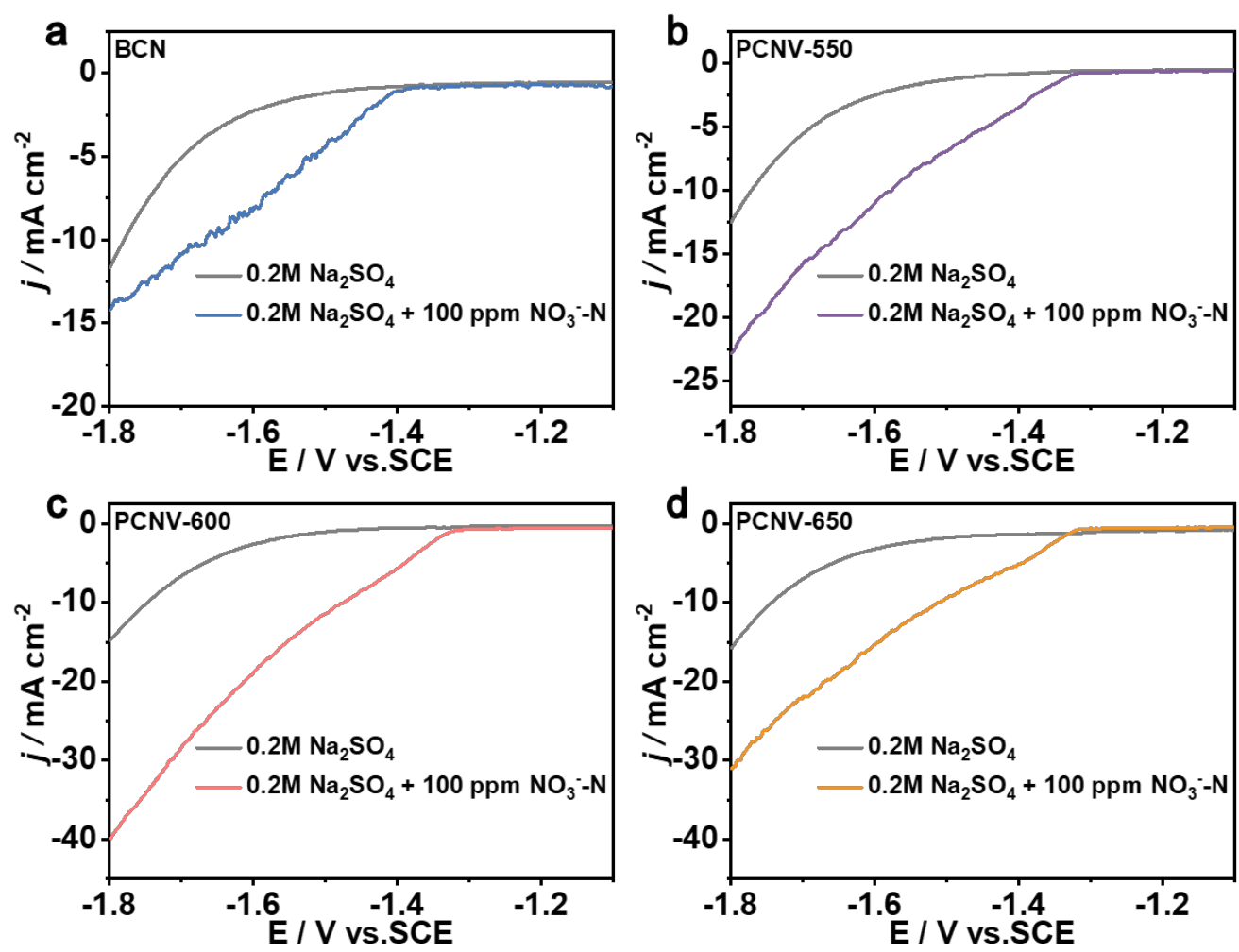

Figure S8. LSV curves of a) BCN, b) PCNV-550, c) PCNV-600, and d) PCNV-650 in $0.5 \mathrm{M} \mathrm{Na}_{2} \mathrm{SO}_{4}$ electrolyte with and without $100 \mathrm{ppm} \mathrm{NO}_{3}^{-}-\mathrm{N}$.

The LSV curves all show an evident increase of current density in the presence of $\mathrm{NO}_{3}^{-}$, indicating the occurrence of nitrate electroreduction. 


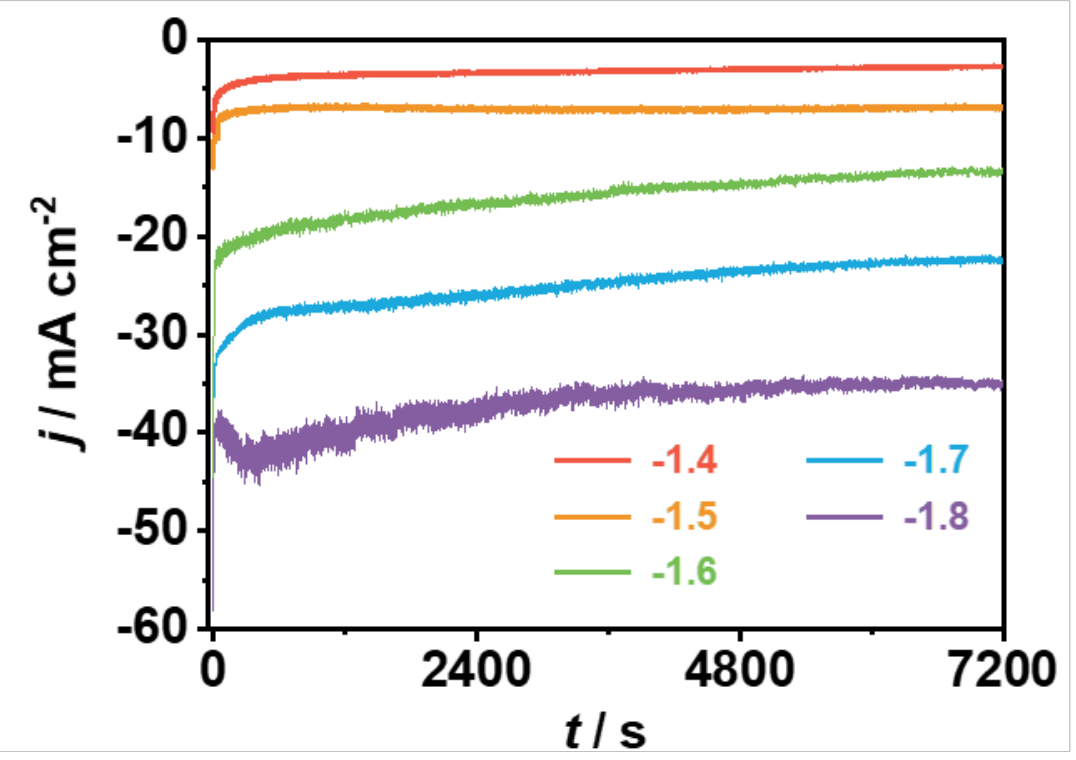

Figure S9. Chronoamperometry curves of PCNV-600 under different applied potential from -1.4 V to $-1.8 \mathrm{~V}$ vs. $\mathrm{SCE}\left(0.5 \mathrm{M} \mathrm{Na}_{2} \mathrm{SO}_{4}\right.$ with $\left.100 \mathrm{ppm} \mathrm{NO}_{3}{ }^{-}-\mathrm{N}\right)$.

Potentiostatic curves of PCNV-600 under different potentials display a slight decrease at the initial stage due to the double layer charging phenomenon ${ }^{7}$ and then maintain well for $2 \mathrm{~h}$. 


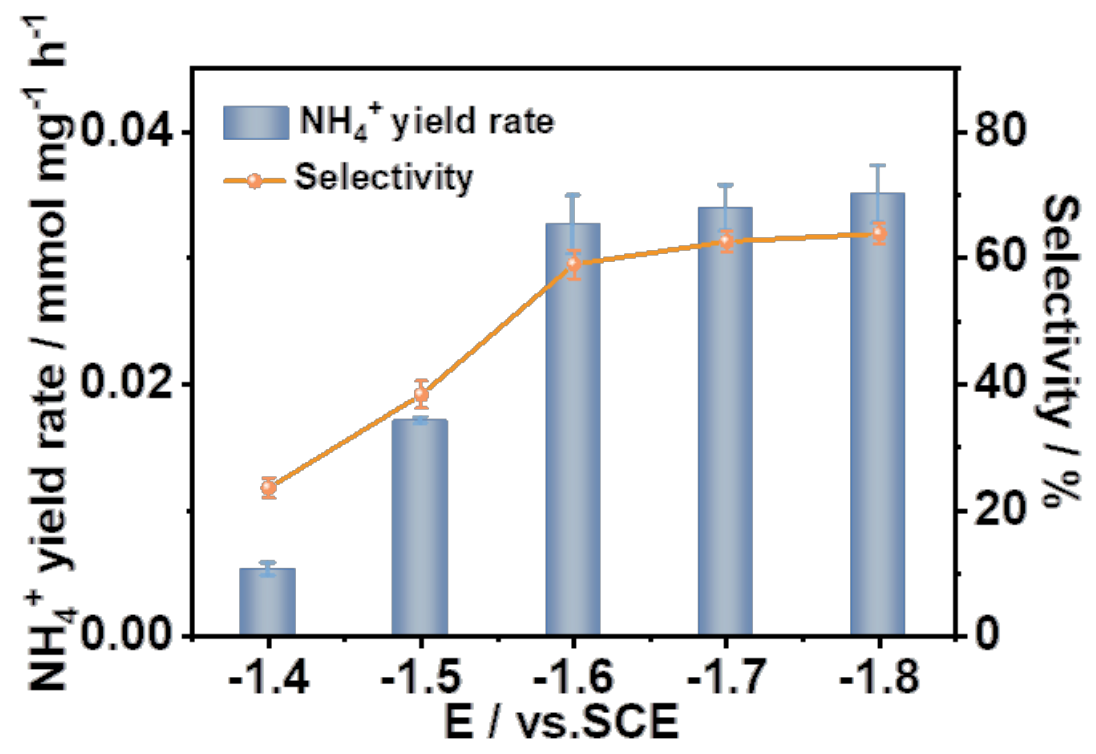

Figure S10. The ammonia yield rate and selectivity at different potentials over PCNV-600.

The yield rate and selectivity of ammonia over PCNV-600 increase first and then stabilize with the potential increase from $-1.4 \mathrm{~V}$ to $-1.8 \mathrm{~V}$ vs. SCE. The highest ammonia yield rate and selectivity can reach $0.035 \mathrm{mmol} \mathrm{mg}^{-1} \mathrm{~h}^{-1}$ and $63.86 \%$ at $-1.8 \mathrm{~V}$ vs. SCE. 


\section{$100 \mathrm{~nm}$}

Figure S11. HRTEM image of PCNV-600 after the cycle test.

The porous nanosheet morphology of PCNV-600 maintains well after the cycle test. 


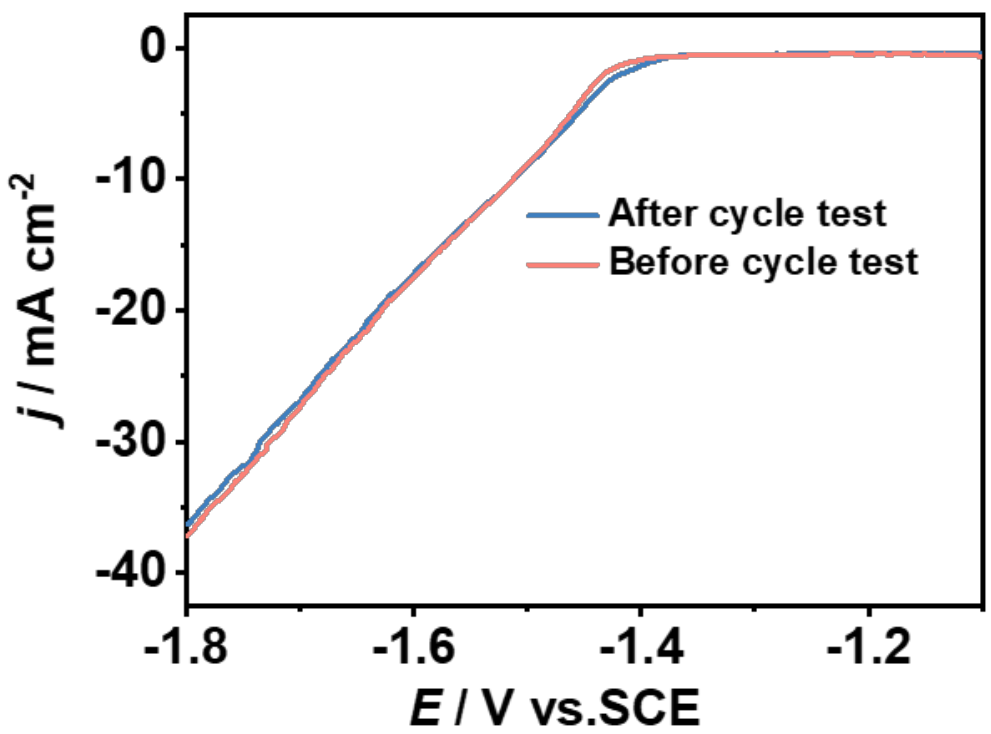

Figure S12. LSV curves of PCNV-600 before and after the cycle experiments.

The LSV curves before and after the cycle test nearly coincide with each other, indicating the high stability of PCNV-600. 


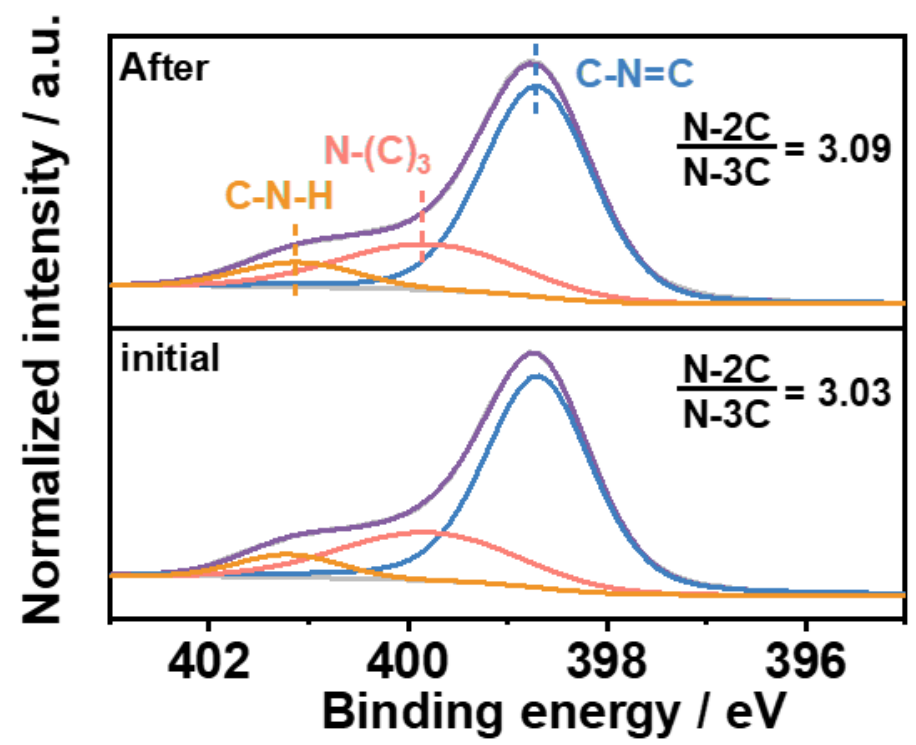

Figure S13. N 1s XPS spectra of PCNV-600 before and after the stability test.

After the stability test, the three main characteristic peaks at $401.1 \mathrm{eV}, 399.8 \mathrm{eV}$, and $398.7 \mathrm{eV}$, assigned to C-N-H, N-3C, and N-2C coordination remained well. Specifically, the integral area ratio between $\mathrm{N}-2 \mathrm{C}$ and N-3C is 3.09 after the stability test, indicating the well remains of NVs structure in PCNV-600. 


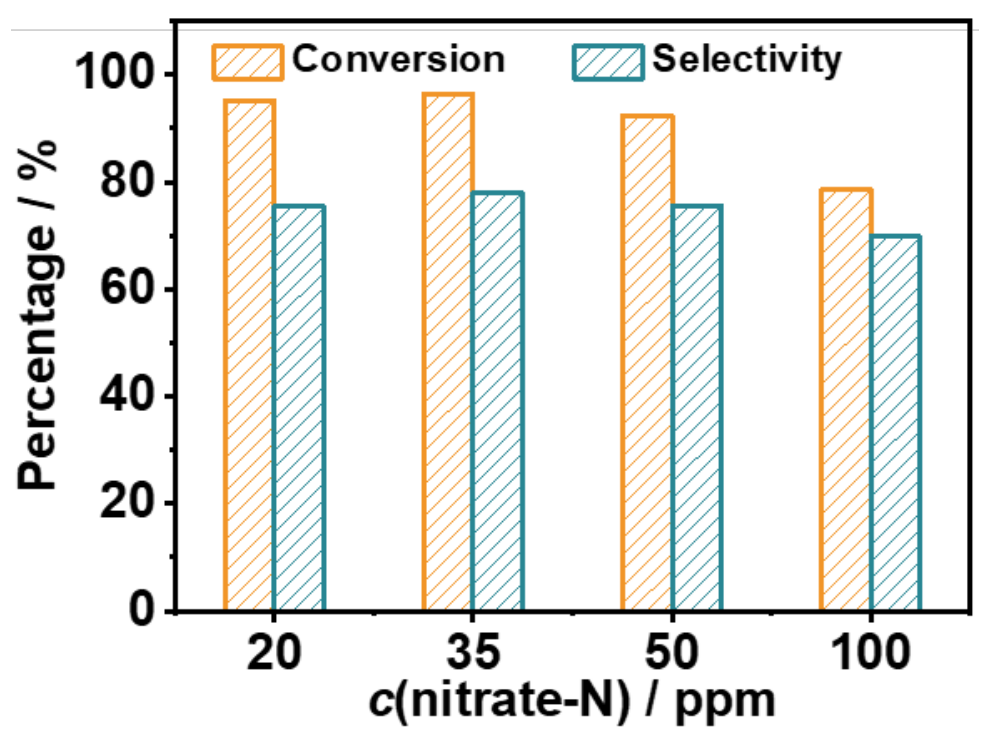

Figure S14. The nitrate conversion rate and the ammonia selectivity with different concentrations of nitrate.

At lower nitrate concentration, the conversion rate of nitrate could reach $\sim 95 \%$ and the selectivity of ammonia is about $\sim 80 \%$. 
a

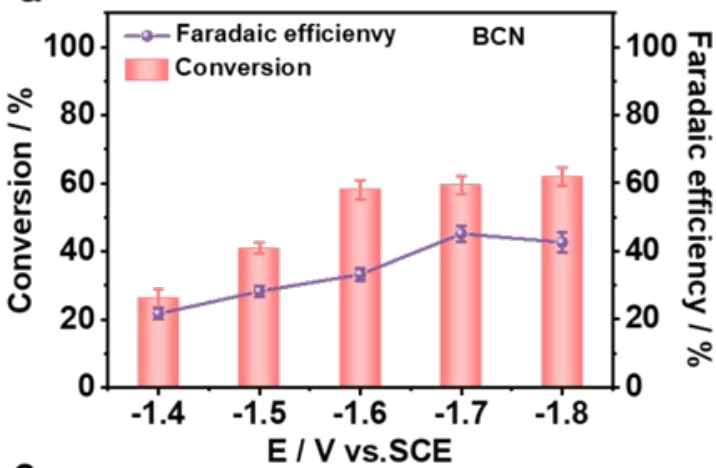

C

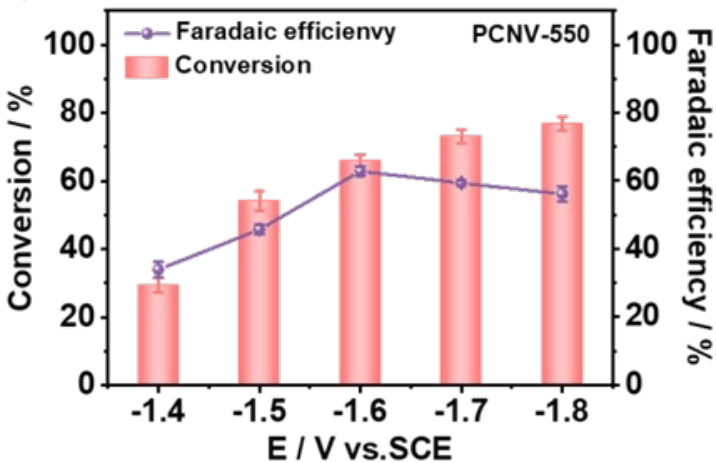

e

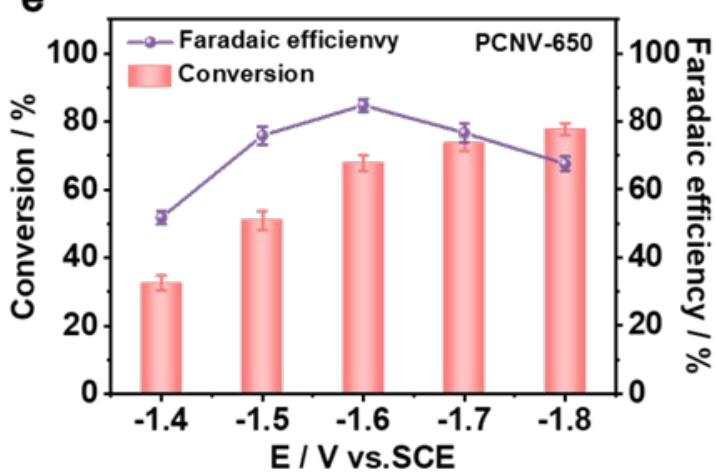

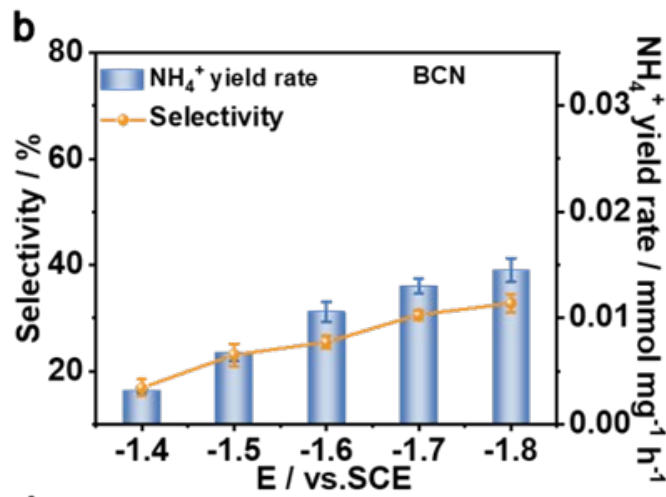

d
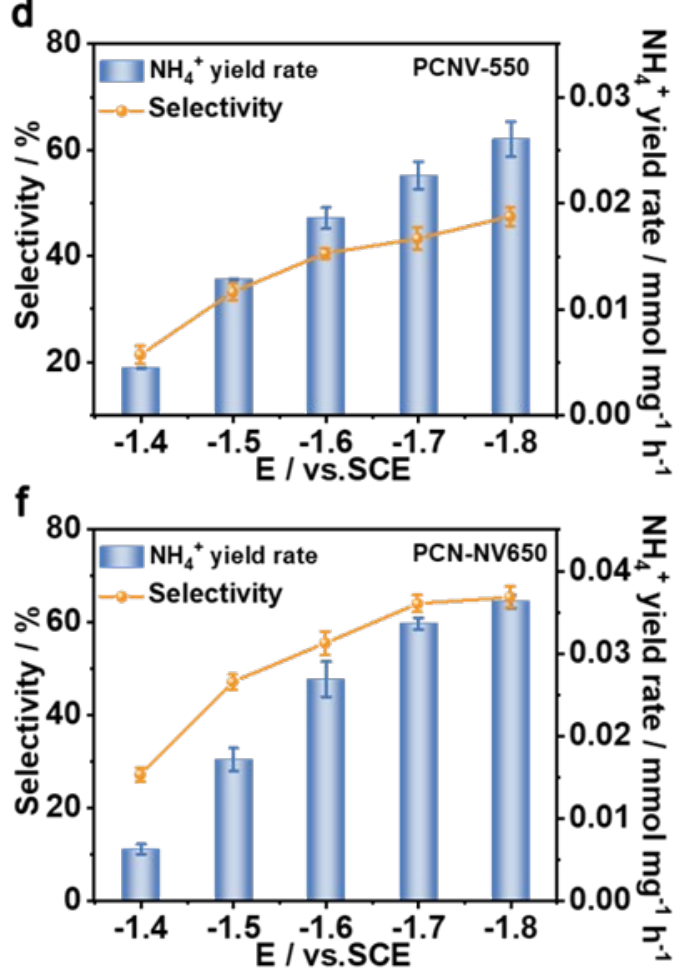

Figure S15. The NRA performance of $\mathrm{BCN}$ a) and b), PCNV-550 c) and d), and PCNV-650 e) and f). 

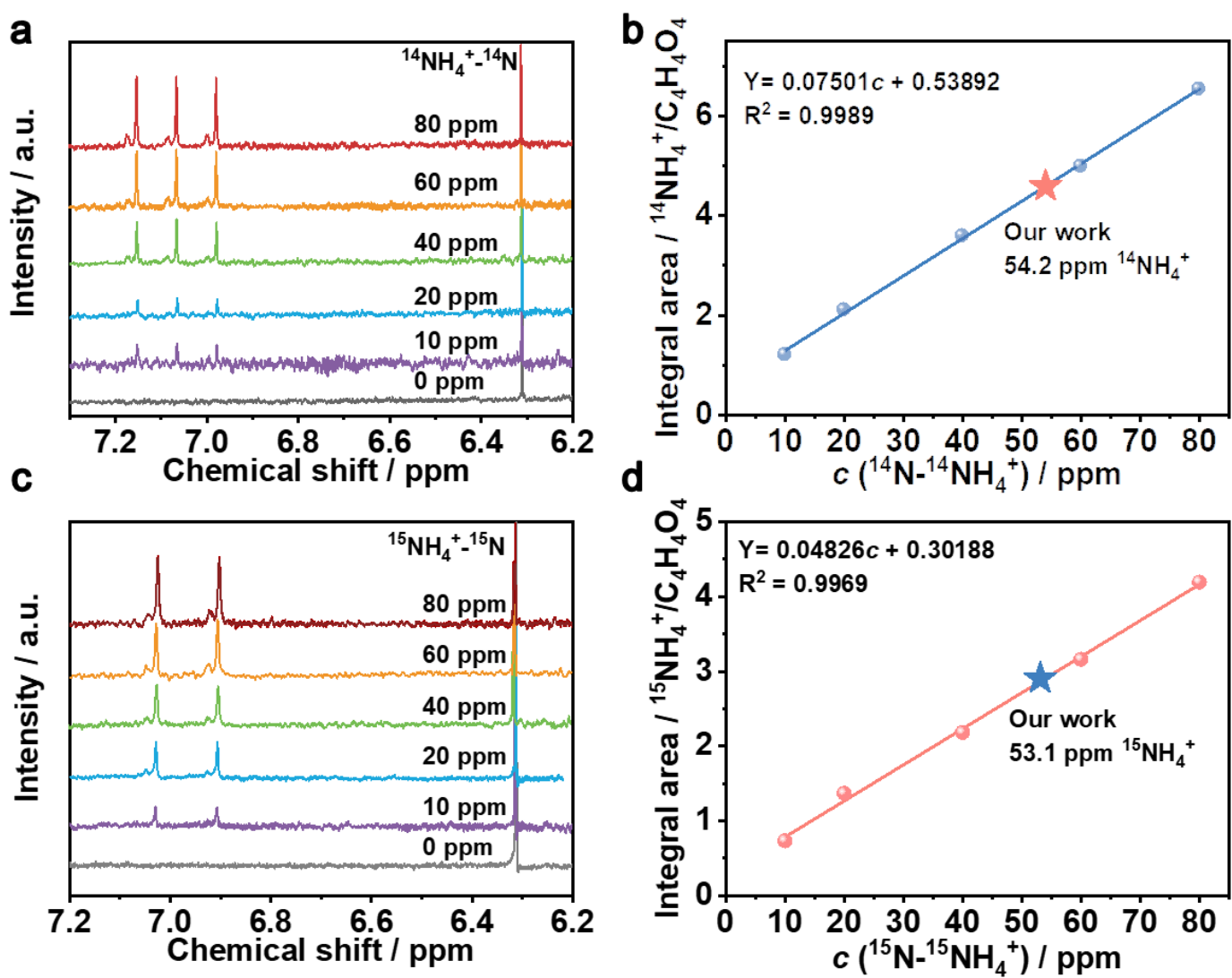

Figure S16. ${ }^{1} \mathrm{H}$ NMR spectra $(600 \mathrm{MHz})$ of a) ${ }^{14} \mathrm{NH}_{4}{ }^{+}-{ }^{14} \mathrm{~N}$ and b) ${ }^{15} \mathrm{NH}_{4}{ }^{+}{ }^{15} \mathrm{~N}$ with different concentrations. c) The standard curve of integral area $\left({ }^{14} \mathrm{NH}_{4}{ }^{+}-{ }^{14} \mathrm{~N} / \mathrm{C}_{4} \mathrm{H}_{4} \mathrm{O}_{4}\right)$ against ${ }^{14} \mathrm{NH}_{4}{ }^{+}-{ }^{14} \mathrm{~N}$ concentration. d) The standard curve of integral area $\left({ }^{15} \mathrm{NH}_{4}{ }^{+}-{ }^{15} \mathrm{~N} / \mathrm{C}_{4} \mathrm{H}_{4} \mathrm{O}_{4}\right)$ against ${ }^{15} \mathrm{NH}_{4}{ }^{+}-{ }^{15} \mathrm{~N}$ concentration.

The concentration of $\mathrm{NH}_{4}{ }^{+}-\mathrm{N}$ can be quantitatively determined by ${ }^{1} \mathrm{H} \mathrm{NMR}$ with external standards (maleic acid) because the peak area of nuclear magnetic resonance is directly related to ammonia content. The proton signal of maleic acid appears at $\delta=6.31 \mathrm{ppm}$. The ${ }^{1} \mathrm{H}$ NMR spectra of ${ }^{15} \mathrm{NH}_{4}{ }^{+}$ show double peaks at $\delta=7.10$ and 6.98 ppm, while ${ }^{14} \mathrm{NH}_{4}{ }^{+}$show triple peaks at $\delta=7.13,7.05$ and $6.96 \mathrm{ppm}$. 


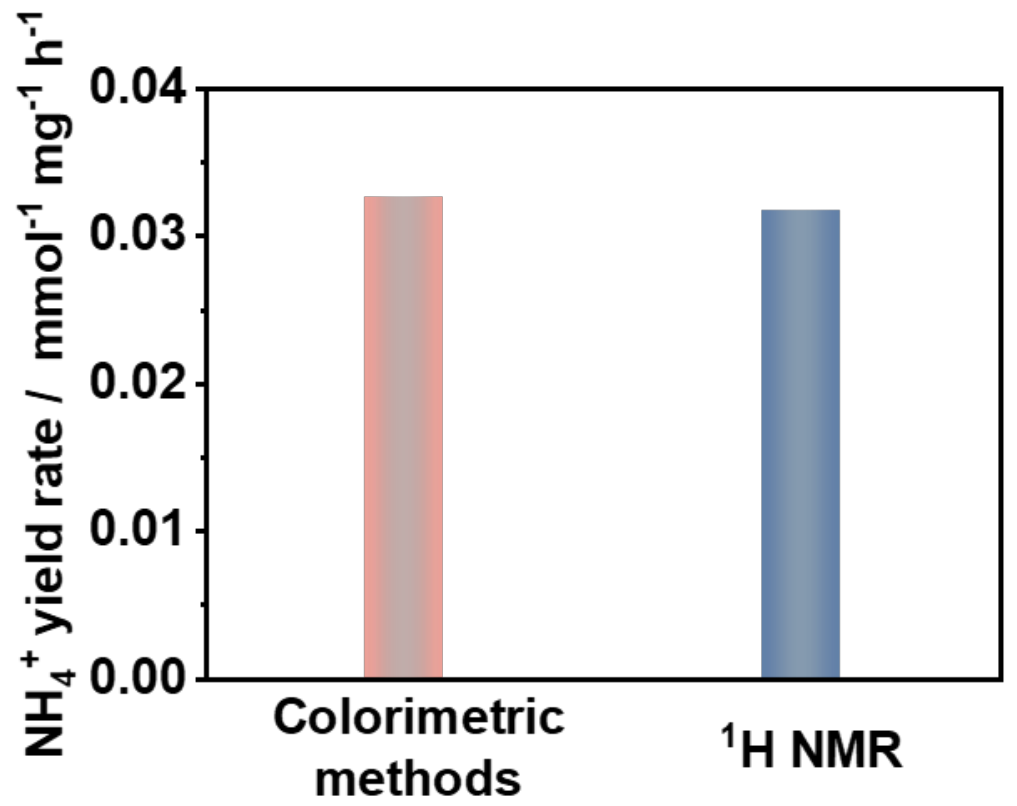

Figure S17. The ammonia yield rate of PCNV-600 at $-1.6 \mathrm{~V}$ vs. SCE calculated by colorimetric methods and ${ }^{1} \mathrm{H}$ NMR methods.

The yield rate of ${ }^{14} \mathrm{NH}_{4}{ }^{+}$calculated by ${ }^{1} \mathrm{H}$ NMR is close to the result obtained by colorimetric method, confirming the reliability of the two methods. 

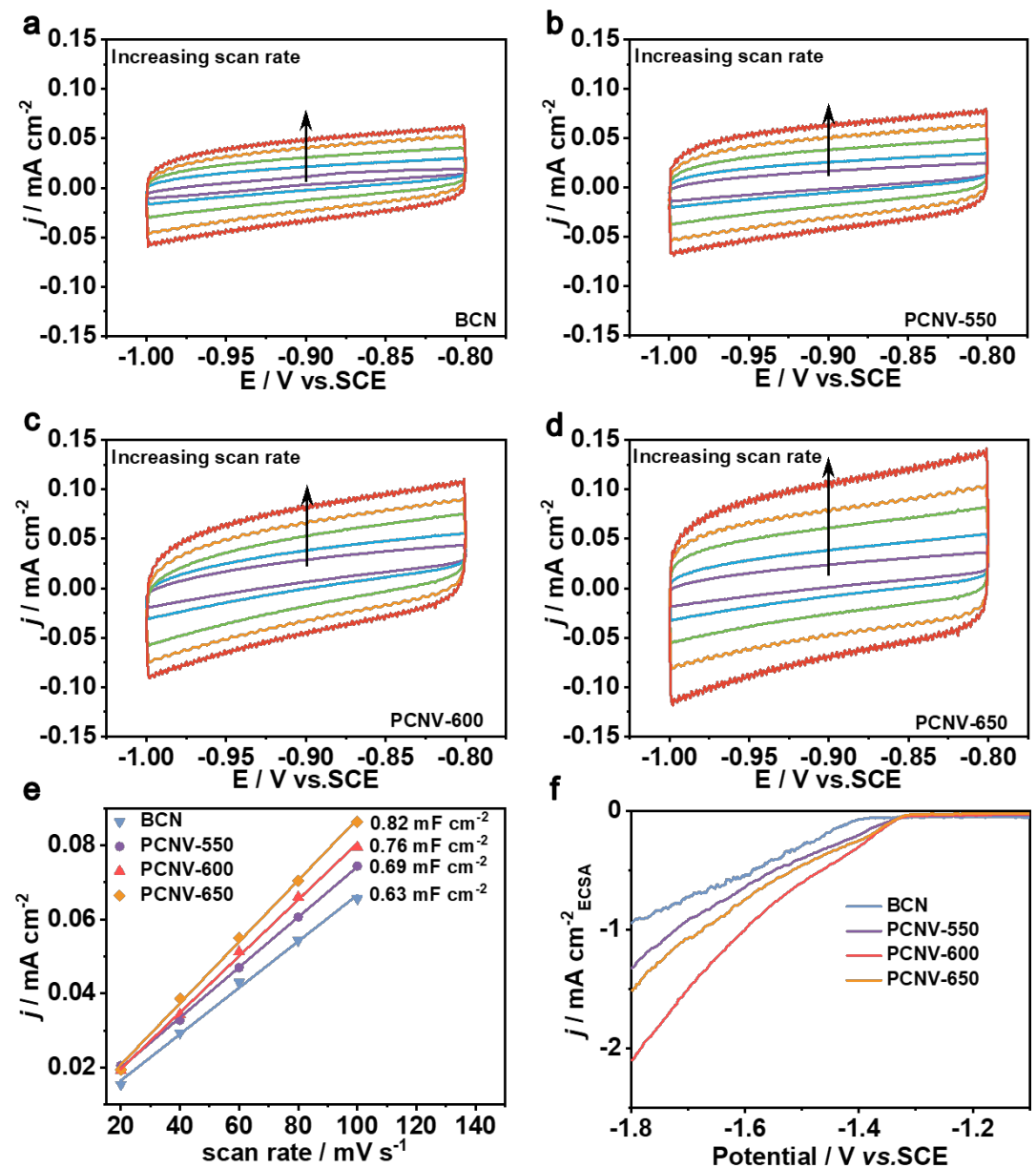

Figure S18. CV curves of a) BCN, b) PCNV-550, c) PCNV-600, and d) PCNV-650 with various scan rates from 20 to $100 \mathrm{mV} \mathrm{s}^{-1}$. e) Plots of the current density versus the scan rate of all the samples. f) The LSV curves normalized to the electrochemical active surface area (ECSA).

Electrochemical capacitance measurements are employed to determine the electrochemical active surface area (ECSA) of the samples. The applied potential scanned from $-0.8 \mathrm{~V}$ to $-1.0 \mathrm{vs}$. SCE at the various scan rates of $20,40,60,80$ and $100 \mathrm{mV} / \mathrm{s}$ in the non-faradic region during the test (Figure S18a-d). Then, the charging current density differences (at the potential of $-0.9 \mathrm{~V}$ vs. SCE) plotted against various scan rates (Figure $\mathrm{S} 18 \mathrm{e}$ ) show that the electrochemical capacitance values of $\mathrm{BCN}$, PCNV-550, PCNV-600 and PCNV-650 are 0.63, 0.69, 0.76 and $0.82 \mathrm{mF} \mathrm{cm}^{-2}$, respectively. Notably, the LSV curve of PCNV-600 after normalized to ECSA (Figure S18f) still exhibits the biggest current density, indicating the highest intrinsic activity of PCNV-600. 


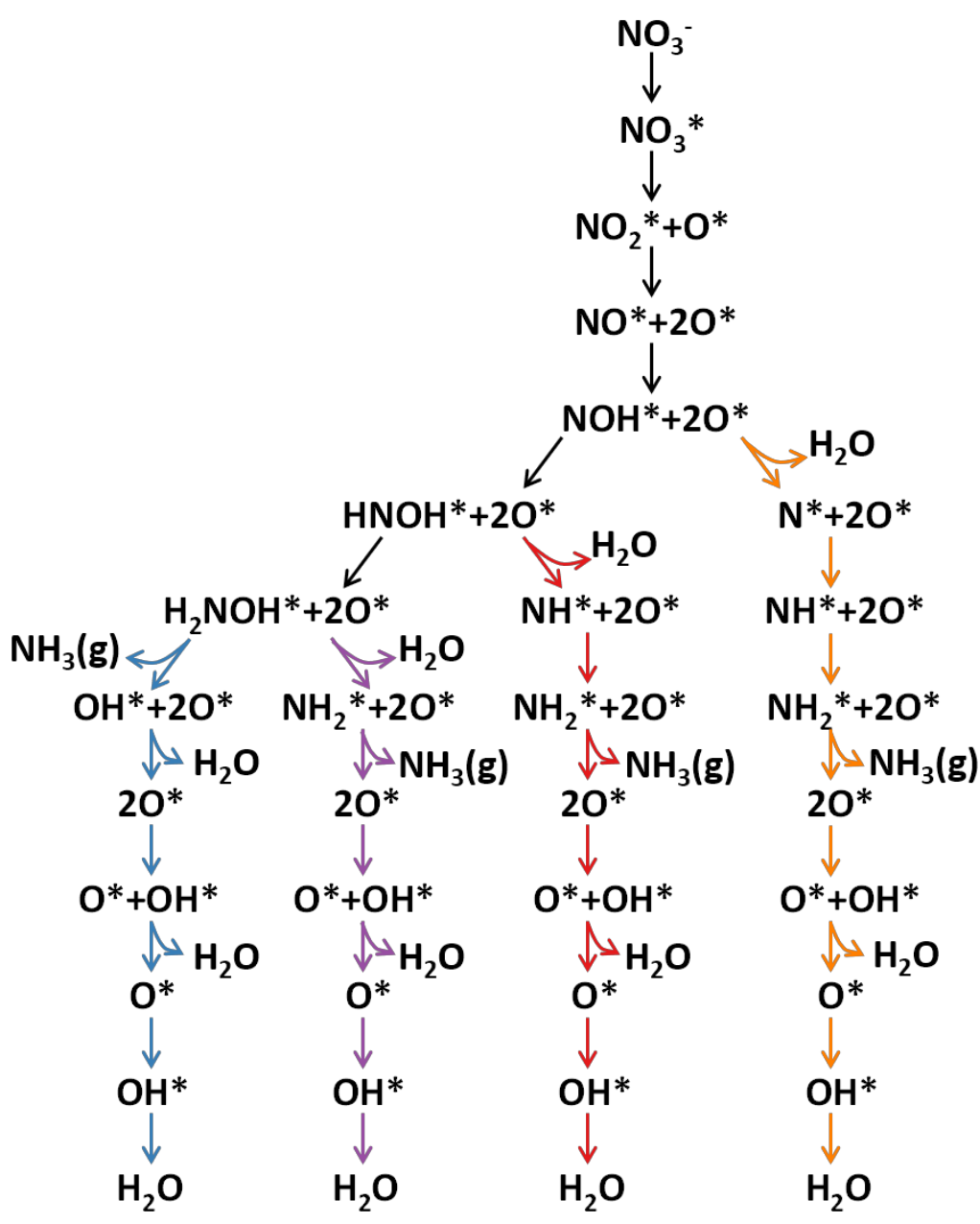

Pathway 2 Pathway 3 Pathway 4 Pathway 1

Figure S19. Four possible reaction pathways for electrochemical nitrate reduction on $g-\mathrm{C}_{3} \mathrm{~N}_{4}$. 


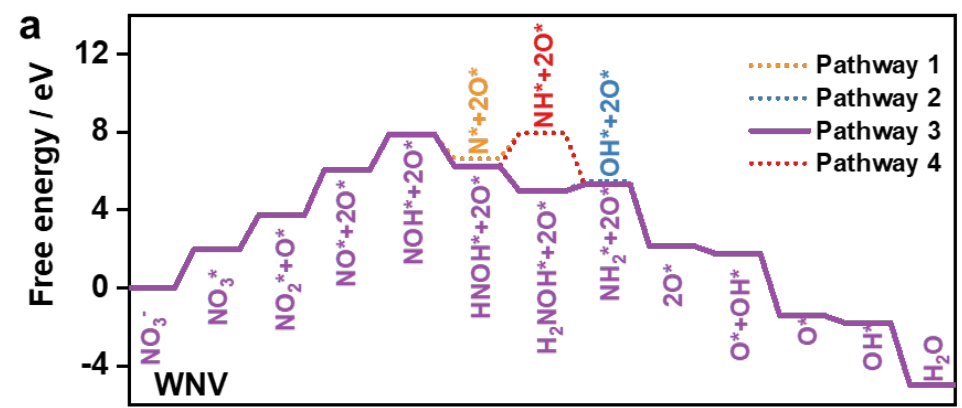

Reaction coordinate

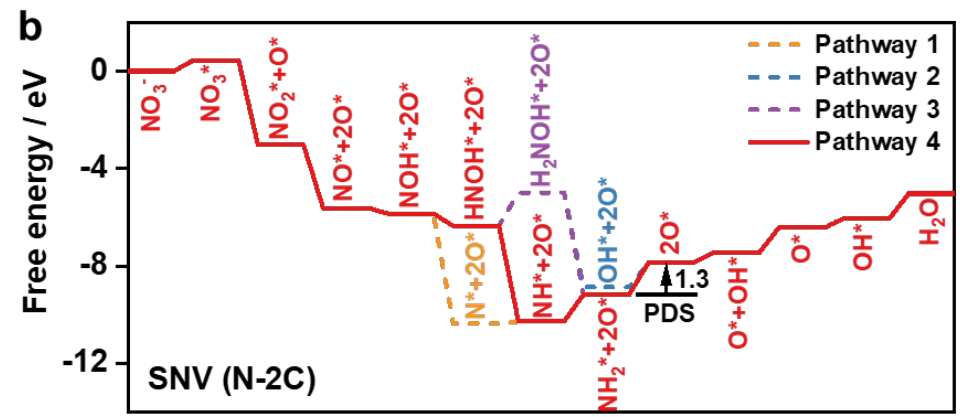

Reaction coordinate

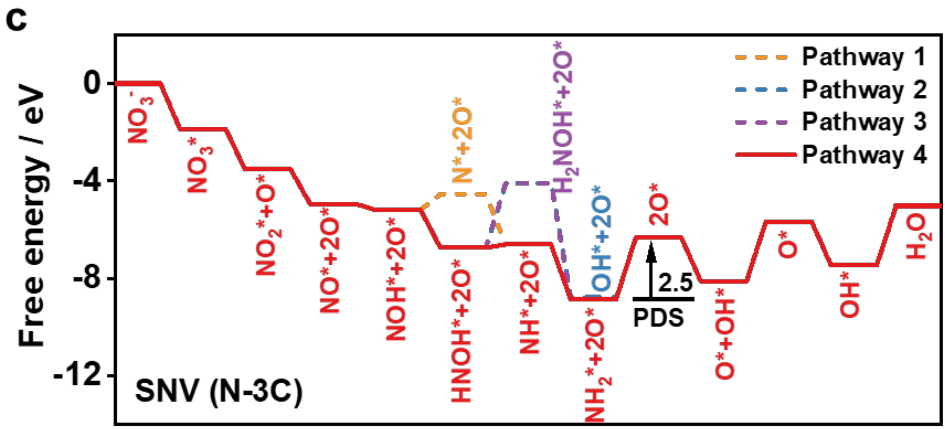

Reaction coordinate

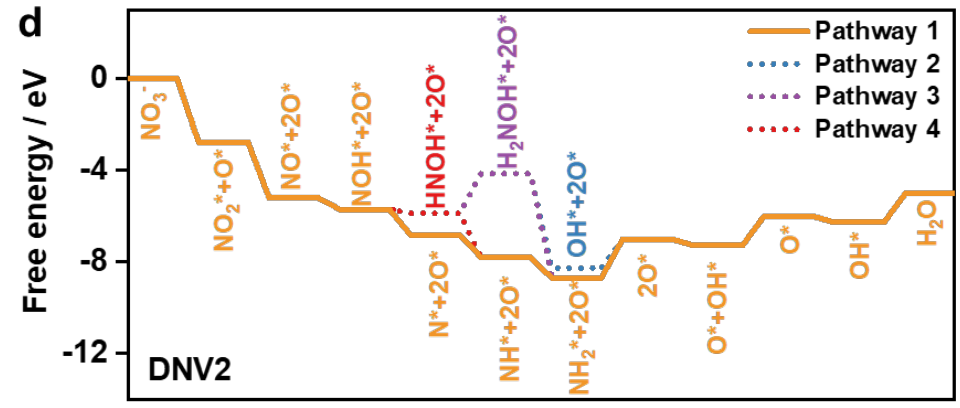

Reaction coordinate

Figure S20. Comparison of different pathways on a) WNV, b) SNV(N-2C), c) SNV(N-3C), and d) DNV. Solid line represents the most optimal pathway.

As shown in Figure S20, the different reaction pathway for nitrate reduction over different configuration of NVs are compared. On WNV, pathway 3 is most preferred due to the smallest limiting 
potential (Figure S20a). Instead, pathway 4 is more preferred on SNV (N-2C) and SNV (N-3C) (Figure $\mathrm{S} 20 \mathrm{~b}$ and $\mathrm{c}$ ), on which, the hydrogenation of $* \mathrm{NH}_{2}$ is the potential-determining step (PDS). The reaction free energy $(\Delta \mathrm{G})$ for the PDS on $\mathrm{N}-3 \mathrm{C}$ configuration is $2.5 \mathrm{eV}$, greater than that on $\mathrm{N}-2 \mathrm{C}(1.3$ $\mathrm{eV}$ ), indicating the dominating role of $\mathrm{N}-2 \mathrm{C}$ in nitrate reduction to ammonia. Thus, $\mathrm{N}-2 \mathrm{C}$ configuration is chosen for subsequently study. The DNV is modeled by two adjacent NVs. The $\mathrm{NO}_{3}^{-}$will spontaneously dissociate into $\mathrm{NO}_{2} *$ and $\mathrm{O} *$ when adsorbed on $\mathrm{DNV}$. Hence the adsorbed $\mathrm{NO}_{3} *$ is not considered in the free energy diagram. Pathway 1 is found the most feasible on DNV. 

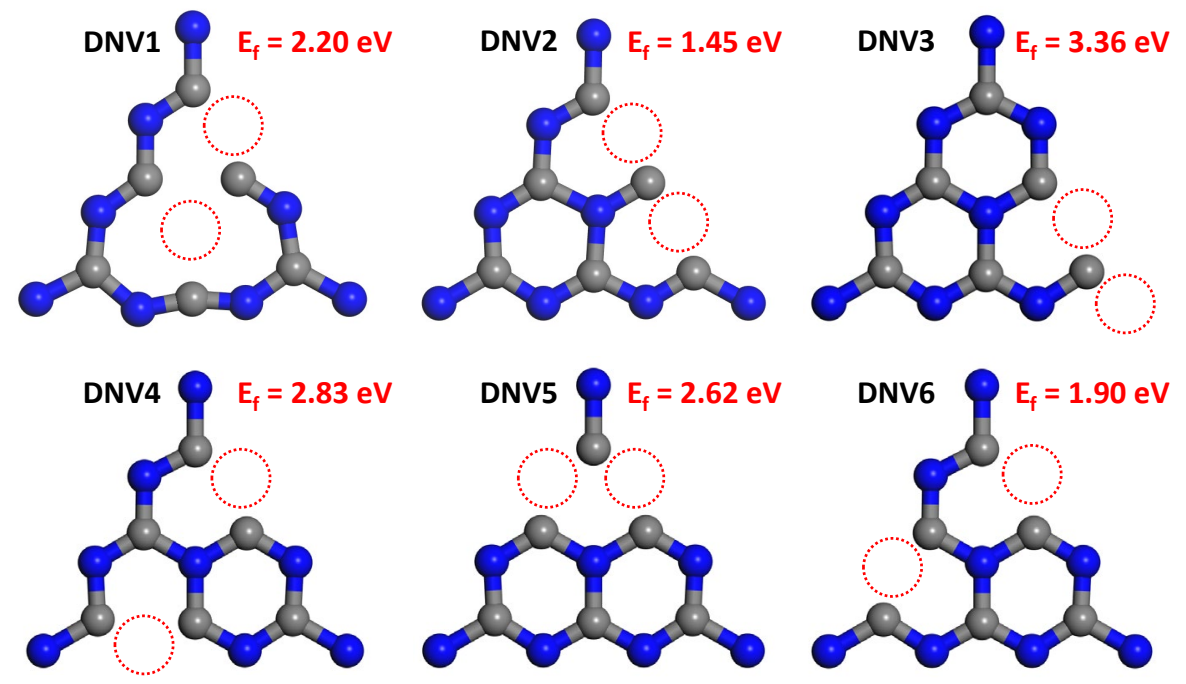

Figure S21. All possible configurations of DNV and corresponding formation energies ( $\left.\mathrm{E}_{\mathrm{f}}\right)$ of vacancy. The grey and blue balls represent $\mathrm{C}$ and $\mathrm{N}$ atoms, respectively 

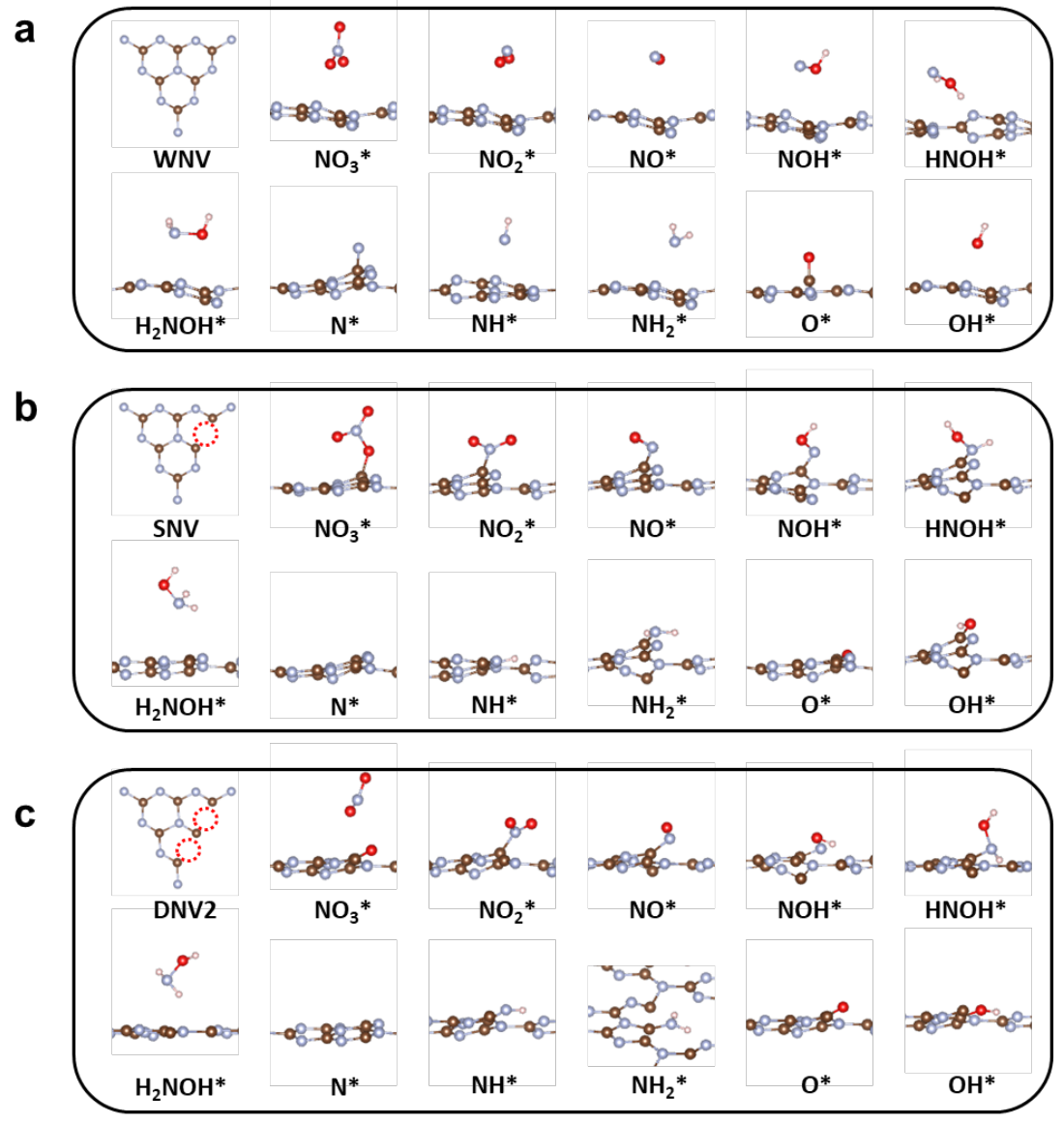

Figure S22. Adsorption configurations of different intermediates on a) WNV, b) SNV, and c) DNV2. The red, brown, grey and pink balls represent $\mathrm{O}, \mathrm{C}, \mathrm{N}$, and $\mathrm{H}$ atoms. The red circles represent nitrogen vacancies. 


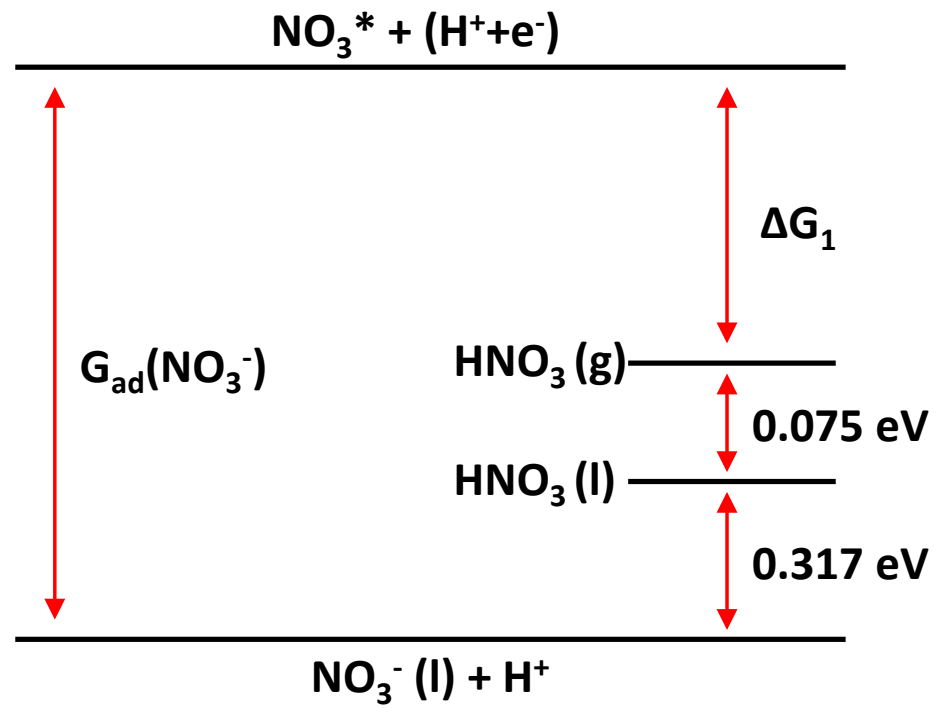

Scheme S1. Illustration for the calculation of adsorption free energy of $\mathrm{NO}_{3}^{-}\left[\mathrm{Gad}_{a}\left(\mathrm{NO}_{3}^{-}\right)\right]$. Scheme adapted from $\operatorname{Ref}^{10}$. The thermodynamic values are obtained from the CRC handbook of chemistry and physics. 
Table S1. Element analysis of different samples.

\begin{tabular}{lcccc}
\hline Sample & N (at.\%) & C (at.\%) & H (at.\%) & C/N \\
\hline BCN & 53.045 & 34.456 & 12.499 & 0.649 \\
PCNV-550 & 52.209 & 34.189 & 13.601 & 0.655 \\
& & & & \\
PCNV-600 & 52.270 & 34.928 & 12.801 & 0.668 \\
PCNV-650 & 51.126 & & & 0.674 \\
\hline
\end{tabular}


Table S2. Summary of the electrochemical performance of non-metallic electrodes in nitrate reduction.

\begin{tabular}{|c|c|c|c|c|c|}
\hline Catalyst & Electrolyte & $\begin{array}{c}\text { Electrolyte } \\
\text { volume (mL) }\end{array}$ & $\begin{array}{l}\text { Ammonia } \\
\text { selectivity }\end{array}$ & $\begin{array}{l}\text { Ammonia } \\
\text { Faradaic } \\
\text { efficiency }\end{array}$ & Ref. \\
\hline PCNV-600 & $\begin{array}{c}100 \mathrm{ppm} \mathrm{NO}-\mathrm{N} \\
0.5 \mathrm{M} \mathrm{Na}_{2} \mathrm{SO}_{4}\end{array}$ & 40 & $69.78 \%$ & $89.96 \%$ & $\begin{array}{l}\text { This } \\
\text { work }\end{array}$ \\
\hline Graphite felt & $2 \mathrm{mM} \mathrm{NaNO}_{3}$ & - & $34.0 \%$ & $15 \%$ & 11 \\
\hline Carbon paper & $\begin{array}{c}50 \text { ppm } \mathrm{NO}_{3}{ }^{-}-\mathrm{N}, 500 \\
\mathrm{ppm} \mathrm{Na}_{2} \mathrm{SO}_{4}\end{array}$ & 200 & $12.9 \% *$ & - & 12 \\
\hline $\begin{array}{l}\text { Boron-doped } \\
\text { diamond (BDD) }\end{array}$ & $\begin{array}{c}65 \mathrm{ppm} \mathrm{NO}_{3}^{-}-\mathrm{N}, 0.1 \\
\mathrm{M} \mathrm{Na}_{2} \mathrm{SO}_{4}\end{array}$ & 1000 & $43.6 \%$ & $19.7 \%$ & 13 \\
\hline BDD & 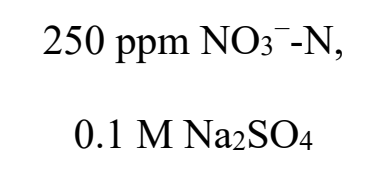 & 1000 & $12.5 \%$ & $128.77 \%$ & 13 \\
\hline BDD & $\begin{array}{c}500 \mathrm{ppm} \mathrm{NO}_{3}{ }^{-}-\mathrm{N} \\
0.1 \mathrm{M} \mathrm{Na}_{2} \mathrm{SO}_{4}\end{array}$ & 1000 & $8.8 \%$ & $256.77 \%$ & 13 \\
\hline BDD & $\begin{array}{l}350 \mathrm{ppm} \mathrm{NO}_{3}^{-}-\mathrm{N}, \\
0.05 \mathrm{M} \mathrm{Na}_{2} \mathrm{SO}_{4},\end{array}$ & 1000 & $3.6 \%$ & - & 14 \\
\hline BDD & $\begin{array}{l}50 \mathrm{ppm} \mathrm{NO}_{3}{ }^{-} \mathrm{N}, \\
1000 \mathrm{ppm} \mathrm{Na}_{2} \mathrm{SO}_{4}\end{array}$ & 50 & - & $8 \%-$ & 15 \\
\hline
\end{tabular}

*: The data is calculated from the paper through the equation listed in the Experimental Section. 


\section{References}

(1). Kresse, G.; Furthmüller, J., Efficient iterative schemes for ab initio total-energy calculations using a plane-wave basis set. Phys. Rev. B 1996, 54 (16), 11169-11186.

(2). Kresse, G.; Furthmüller, J., Efficiency of ab-initio total energy calculations for metals and semiconductors using a plane-wave basis set. Comp. Mater. Sci. 1996, 6 (1), 15-50.

(3). Zhang, Y. K.; Yang, W. T., Comment on "Generalized gradient approximation made simple". Phys. Rev. Lett. 1998, 80 (4), 890-890.

(4). Grimme, S.; Antony, J.; Ehrlich, S.; Krieg, H., A consistent and accurate ab initio parametrization of density functional dispersion correction (DFT-D) for the 94 elements H-Pu. J. Chem. Phys. 2010, $132(15), 154104$

(5). Nørskov, J. K.; Rossmeisl, J.; Logadottir, A.; Lindqvist, L.; Kitchin, J. R.; Bligaard, T.; Jónsson, H., Origin of the Overpotential for Oxygen Reduction at a Fuel-Cell Cathode. J. Phys. Chem. B 2004, $108(46), 17886-17892$.

(6). Zhao, D.; Wang, Y.; Dong, C.-L.; Huang, Y.-C.; Chen, J.; Xue, F.; Shen, S.; Guo, L., Boron-doped nitrogen-deficient carbon nitride-based Z-scheme heterostructures for photocatalytic overall water splitting. Nat. Energy 2021, 6 (4), 388-397.

(7). Meng, N.; Ren, J.; Liu, Y.; Huang, Y.; Petit, T.; Zhang, B., Engineering oxygen-containing and amino groups into two-dimensional atomically-thin porous polymeric carbon nitrogen for enhanced photocatalytic hydrogen production. Energy Environ. Sci. 2018, 11 (3), 566-571.

(8). Chen, Z.; Fan, T.; Shao, M.; Yu, X.; Wu, Q.; Li, J.; Fang, W.; Yi, X., Simultaneously enhanced photon absorption and charge transport on a distorted graphitic carbon nitride toward visible light photocatalytic activity. Appl. Catal. B Environ. 2019, 242, 40-50. 
(9). Kang, Y.; Yang, Y.; Yin, L. C.; Kang, X.; Liu, G.; Cheng, H. M., An Amorphous Carbon Nitride Photocatalyst with Greatly Extended Visible-Light-Responsive Range for Photocatalytic Hydrogen Generation. Adv. Mater. 2015, 27 (31), 4572-7.

(10). Liu, J.-X.; Richards, D.; Singh, N.; Goldsmith, B. R., Activity and Selectivity Trends in Electrocatalytic Nitrate Reduction on Transition Metals. ACS Catal. 2019, 9 (8), 7052-7064.

(11). Ding, J.; Li, W.; Zhao, Q.-L.; Wang, K.; Zheng, Z.; Gao, Y.-Z., Electroreduction of nitrate in water: Role of cathode and cell configuration. Chem. Eng. J. 2015, 271, 252-259.

(12). Rao, X.; Shao, X.; Xu, J.; Yi, J.; Qiao, J.; Li, Q.; Wang, H.; Chien, M.; Inoue, C.; Liu, Y.; Zhang, J., Efficient nitrate removal from water using selected cathodes and $\mathrm{Ti} / \mathrm{PbO} 2$ anode: Experimental study and mechanism verification. Separation and Purification Technology 2019, 216, 158-165.

(13). Ghazouani, M.; Akrout, H.; Bousselmi, L., Efficiency of electrochemical denitrification using electrolysis cell containing BDD electrode. Desalin Water Treat. 2015, 53 (4), 1107-1117.

(14). Ghazouani, M.; Akrout, H.; Jomaa, S.; Jellali, S.; Bousselmi, L., Enhancing removal of nitrates from highly concentrated synthetic wastewaters using bipolar Si/BDD cell: Optimization and mechanism study. J. Electroanal. Chem. 2016, 783, 28-40.

(15). Kuang, P.; Natsui, K.; Einaga, Y., Comparison of performance between boron-doped diamond and copper electrodes for selective nitrogen gas formation by the electrochemical reduction of nitrate. Chemosphere 2018, 210, 524-530. 